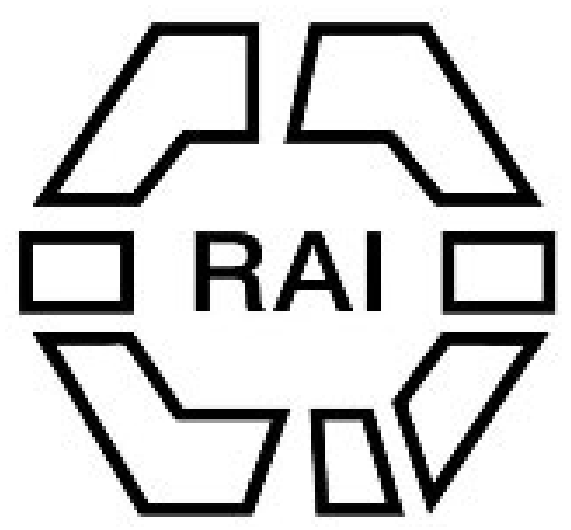

Rag-Bushes and Kindred Observances.

Author(s): M. J. Walhouse

Source: The Journal of the Anthropological Institute of Great Britain and Ireland, Vol. 9 (1880), pp. 97-106

Published by: Royal Anthropological Institute of Great Britain and Ireland

Stable URL: http://www.jstor.org/stable/2841872

Accessed: 15/06/2014 08:04

Your use of the JSTOR archive indicates your acceptance of the Terms \& Conditions of Use, available at http://www.jstor.org/page/info/about/policies/terms.jsp

JSTOR is a not-for-profit service that helps scholars, researchers, and students discover, use, and build upon a wide range of content in a trusted digital archive. We use information technology and tools to increase productivity and facilitate new forms of scholarship. For more information about JSTOR, please contact support@jstor.org. 


\title{
RAG-BUSHES and KINDRED OBSERVANCES.
}

\author{
By M. J. Walhouse, Esq., F.R.A.S.
}

IN a paper on "Non-sepulchral Rude Stone Monuments" which I had the honour to read before the Institute in February, 1877, an allusion to the practice of tying pieces of rag to bushes at spots where persons had been killed, or died in any unusual way, gave rise to some remarks and appeared to excite some interest. I have since collected some more instances, and put together a few observations on the subject, which I now venture to submit.

The meaning and intention of the custom seem sometimes votive and sometimes commemorative, a mark of respect or worship, or an offering to avert evil or show gratitude for benefits received. The earliest instance recorded seems to approach tree-worship, where Herodotus relates (vii, 31) that Xerxes when marching on Greece, encountered in Lydia a planetree so beautiful that he commanded it to be decorated with gold robes and ornaments, and left one of his " band of immortals" to guard it. The historian says this was simply on account of

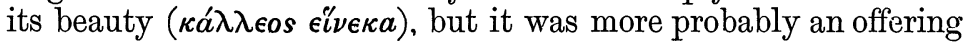
to some sacred tree: an object doubtless then, as now, familiar to the Persians in their own country. So, too, the Arabian annalist of the ninth century, Tabari, relates that the people of Najrân in Yemen, every year on a certain day assembled round a large date-tree outside the city, hung it with rich garments, and offered prayers to a spirit that spoke to them from the tree.* From many passages in the classical writers, it will be sufficient to refer to the eighteenth Idyll of Theocritus, where the Spartan virgins are represented hanging lotus-wreaths on a plane-tree consecrated to Helen, there worshipped as a deity, and to the grove sacred to Ceres described by Ovid, in which stood a huge and ancient oak, covered all over with wreaths, garlands, and tablets, memorials of vows and evidences of their powerful effect. $\dagger$

In Southern India, besides the custom of tying bits of cloth and rags to bushes at spots where men have met with violent deaths, a custom also recently noted by correspondents with our

* Compare Jeremiah x, 3, 4. "One cutteth a tree out of the forest; they deck it with silver and with gold."

$\dagger$ "Stabat in his ingens annoso robore quercus,

Una nemus; vittæ mediam, memoresque tabellæ,

Sertaque cingebant, voti argumenta potentis."

VOL. IX.

"Metam." viii, 741.

$\mathrm{H}$ 


\section{M. J. Walhouse.-Rag-Bushes and Kindred Observances.}

troops in Afghanistan, there is a practice of sticking rags on a certain prickly shrub, the botanical name of which I do not know, but the prickles have a venomous quality and cause a feverish burning, said to be worse at some seasons than others, to avert which bits of rag are stuck on, occasionally covering all the branches, apparently as a propitiation directly to the bush itself, for I could not learn that any spirit was supposed to inhabit it. Again, the tombs of Mussulman saints and holy men, continually met with in all sorts of localities in India, are frequently surrounded with tall upright canes and rods to which are attached streamers of many-coloured rags.*

Another variant, as it seemed to me, of the custom, I once met with in a wild sequestered valley at the foot of the Great Arnemally Mountain-range in Coimbatore, Madras. At its top there is an ancient place of pilgrimage, known as Trimurti, or Trinity, Temple. A stream rushes down a steep mountain cleft, and where it reaches the plain a great broad boulder, some forty feet high, rises from its bed, bearing on one side the indistinct outlines of three personages seated together. Near this, eight stone images are set in a circle, with faces inwards, round a fine granite pillar, and close by are some large champaca and other flower-bearing trees, to the branches of which are suspended scores of native sandals or shoes, some old and worn, some quite new with elaborately worked and ornamented latchets, and some of Brobdingnagian proportions, evidently specially made for the purpose. Pilgrims come from afar to this spot, which just there is the watershed of the Peninsula, and hang up the shoes in evidence of vows accomplished or as thank-offerings for wishes granted; the enormous shoes seem analogous to the huge candles vowed in Catholic times. $\dot{\top}$

On the Himâlaya Mountains the Mâni or long heaps of stone, that form so remarkable a feature, are often stuck over with flags and scraps of inscribed paper, and in Tartary and Thibet the missionaries Huc and Gabet describe the Oboes, or immense cairns, they often encountered, as surmounted with branches hung over with strips of cloth on which are written verses; one such is figured at page 25, vol. i, English edition. These are evidently propitiatory offerings to the mountain spirits. In

* "The burial grounds (near Bombay) were full of little flags or pennants, like those on a lance." ("Arabia, Egypt, India." Mrs. R. Burton, p. 128.)

† Another variant appears to be a custom of the Garros, immemorially dwellers in the deep jungle-tracts on the Eastern border of India. Over each path leading into a village a bamboo arch, decorated with tufts of cotton, is at certain times raised to propitiate deities. All who enter or quit the village must pass under these arches. They are as often placed over the door of the house in cases of sickness. 
China, pieces of gilded paper are hung upon trees in sacred places, and at periodical times of mourning. Governor Davis describes the whole population of towns trooping out to the hills to make offerings at the tombs, "leaving behind them long streamers of red and white paper to mark the fulfilment of the rites; whole ranges of hills sprinkled with tombs may at that season be seen covered with these testimonials of attention to the departed, fluttering in the wind and sunshine" (Davis's "Chinese," vol. i. c. 8). In remoter Asia and Eastern Europe, Strahlenberg describes the Jakuhti of Eastern Siberia as "hanging all manner of nicknacks" on their sacred trees, "and the Scheremissi by the Volga hanging the hides and bones of cattle on their holy trees "to rot by way of sacrifice in the air" ("Description of Northern and Eastern Europe and Asia," pp. 354, 381). In the Journal of this Institute, vol. ii. p. 120, the same author is quoted representing the idols of the Ostiaks on the Rivers Irtysch and Obi, as "roughly hewn pieces of wood hung over with rags."

Returning to more civilised regions of Asia, the prevalence of the custom in Persia has attracted the notice of travellers for centuries. Sir John Chardin, in his "Travels in Persia, \&c., in the Seventeenth Century," often mentions the sacred trees, and in particular describes a very ancient plane in one of the King's gardens at Shiraz, to which the people used to come and pray under its shade, and hang to its branches garlands, amulets, and bits of their garments. The sick, or their friends for them, used also to come and stick lights* on it in the hope to recover health. Sir John adds that such trees are met with everywhere in Persia, and called dirakht-fazel, i.e. excellent trees; one sees them, he says, stuck all over with nails for fastening on bits of garments. ("On les voit tout lardes de clous pour y attacher des pièces d'habillements." "Travels," vol. viii. 426-7, ed. Paris, 1811). At Ispahan too he saw another such plane-tree, "tout herissé de clous et de pointes." This brings to mind the "Stock am Eisen," the aged trunk, only relict of the sacred grove of heathen days, still, I believe, standing in Vienna, into which every apprentice starting on his Wanderjahre drove a nail for luck. $\dagger$ In later times Mr. James Morier, in his "Second Journey through Persia, Armenia, and Asia Minor" in 1810...20, writes (page 239): "Close to the burial-place of a Persian saint grew a small bush, upon the branches of which were tied a variety of rags and remnants of garments. The Persians conceive that

* So still done in Livonia. See "Journal Anthrop. Inst.," vol. iii, 276.

$\dagger$ The Romans drove nails into the walls of cottages to avert the plague; and in Cornwall and Oldenburg a nail driven with certain observances into an oak tree is reported to cure tooth-ache. 
those rags from their vicinity to the saint acquire peculiar preservative virtues against sickness, and substituting others, they take bits away, and tying them about their persons, use them as talismans." This idea was not unknown in Europe in connection with holy wells, writing on which Brand, in his "Popular Antiquities," refers to a prayer of the Roman Church used for the blessing of clouts in the way of the cure of diseases. Morier, at the passage just quoted, mentions the " handkerchiefs and aprons" brought from the body of St. Paul, which banished diseases and evil spirits (Acts xix, 12) as involving the same belief.* The habit of tying up bits of rag prevails amongst the Mahometans everywhere from India to Palestine, and Captain Conder, in "Tent-work in Palestine" (vol. ii, 233), gives one of the most recent notices of it, observing: "Amongst the peculiar religious institutions of the country are the sacred trees, generally oaks or terebinths, $\dagger$ with names taken from some Sheikh to whom they belong; they are covered all over with rags, tied to the branches, which are considered acceptable offerings." $\ddagger$

In Africa notices of the custom are more scanty. Mungo Park ("Travels," p. 65, 8vo. ed.) has a curious account, quoted also by Brand, of a great tree called Neema Taba, "decorated with innumerable rags or scraps of cloth," which persons travelling by had tied to its branches, and none now "presumed to pass without offering something." Park himself, as though emulating Xerxes of old, suspended a handsome piece of cloth on one of the boughs. I do not remember that any of the more recent illustrious band of explorers, from Livingstone to Stanley, mentions having observed the custom. In Northern Africa, however, Colonel Keatinge noticed " rags, potsherds, and the like trash" strung upon wild olive-bushes near Mogadore, and on being unable to obtain an explanation, remarks "a traveller will see precisely the like in the West of Ireland, and will receive

* See, too, 2 Kings xiii, 24, where the touch of Elisha's grave-clothes revires a dead man. In medieval times, the clothes of saints daily worked miracles, and in 1846 the sight alone of the Holy Coat at Treves cured many afflicted.

+ The tree planted by the Patriarch Sheikh Abraham (Genesis xxi, 33) was eshel-an oak or terebinth.

\$ The accounts of Chardin and Morier are curiously confirmed by Mr. Eugene Schuyler, who in bis "Turkistan," published in 1876, says of the tomb of Zangata, the patron saint of Tashkend, "that it looks shabby from the rams' horns and long bits of dirty rag which every pilgrim has felt it necessary to tie there on some stick or tree. Old trees, especially old mulberry trees, seem greatly venerated throughout Central Asia, and the older and deader they are the more bits of rag they have stuck on them, which are symbols of sacrifice" (Vol. $i$, 138).

Mr. J. Romilly Allen also informs me that in 1874 he observed by the highroad which crosses the Elburz Mountains by the Khorzam Pass, at a height of 7,000 feet above the sea, a great number of thorn-bushes covered with rags of every colour, which had been left by the muleteers. 
an equally satisfactory account upon the subject" " Travels in Europe and Africa," p. 186), but this again was in a Mahometanpeopled region.

In the New World there is evidence of the existence of the custom from the North to the extreme South. Sir John Lubbock (" Origin of Civilisation," pp. 196-97) adduces (1) Sir J. Franklin's description of a sacred tree on which the Cree Indians had hung strips of buffalo flesh and pieces of cloth; and (2) Mr. Tylor's account of the great cypress in Mexico, its branches covered with hundreds of locks of coarse hair, teeth, bits of coloured cloth, rags and morsels of ribbon, "probably so decorated long before the discovery of America;" and (3) lastly, Mr. Darwin's notice of the remarkable single-standing sacred tree in Patagonia, reverenced by all the Indians, with numberless offerings, "such as cigars, bread, meat, pieces of cloth, \&c.," suspended to its branches by threads.*

In Australia the custom does not appear to exist, nor yet in the South Sea Islands, unless there is something analogous in the consecration by tabu, "which is generally marked by small white flags or other signs," stuck about tabued property (Jarves' "History of the Sandwich Islands," p. 56). Fruit trees, groves, \&c., are also marked as tabued by charms of various sorts hung' upon them.

In Europe the rag-tying habit is and has from time immemorial been widely spread; instances of its prevalence throughout the British Islands are given in numerous works. Brand in his book on "Popular Superstitions" speaks of rag-bushes existing in his day near Newcastle-upon-Tyne, and adduces a number of instances in Wales and Scotland. These bushes were always associated with holy wells, where sick persons bathing or drinking left bits of their clothing tied to adjacent bushes as offerings ; just as in Persia devotees tie rags to bushes near holy tombs. In Ireland the custom probably still exists.

In the Journal of this Institute, vol. iii, 276 , there is a curious notice of the survival of tree-worship in Esthonia in our own times ; and Boyle, in his "Historical and Critical Dictionary," quotes a passage from a work on "Idolatry" by Rubenus, a travelling friar, who in 1588 passed through the sacred woods of the Esthonians, and saw there "a pine-tree of extraordinary height and bigness, the branches whereof were full of divers pieces of old cloth, and the roots covered with bundles of straw.

* Over an Indian grave by the Fraser river in British Columbia "the dark green blankets which had covered the Indians in hife now fluttered in the wind, weird-looking ensigns, waiting to be claimed by the spirits of their departed owners, and on a large branch of the nearest tree hung the heads, hides and hoofs of the horses which had carried them through life" ("The Sea of Mounttains," by M. St. John, vol. ii, 135). 
On asking the meaning he was told that the inhabitants adored the tree, and that the women, after a safe delivery, brought thither the bundles of hay" (English Translation, 4th vol. fulio, sub voce "Rubenus"). Being at Freybourg, in Switzerland, in September, three years ago, and descending the precipitous suree to the old part of the town, at the bottom of the deep romantic gorge of the Saarine, where the antique houses and embattled wall with its feudal watch-towers give to the scene a more old-world aspect than elsewhere in Switzerland, I found the market-place en fête, and in its centre an extraordinarily tall straight fir-tree being raised, with all its branches lopped for half their length, and decorated with an infinity of flags; pennons, and festoons of moss and flowers. I found that this was done annually in commemoration of Duke Berchthold de Zæhringen, the half-legendary founder and patron of Freybourg in the twelfth century, a mode of showing honour not impossibly derived from the sacred rag-trees, and tending to support Keysler's opinion that the custom of the Maypole took its rise from the desire of the people to do honour to their king, who, seldom appearing at other times, made at that season a solemn procession to the Great Assembly held in the open air. Such indeed may have been the origin of "the tall Maypole that o'erlooked the Strand,"* not far from this Institute, "that siinking idol" as the old Puritan writer (Stubbs) styles it, "bound about with strings from the top to the bottom, and with handkerchiefs and flags streaming on the top." So that the great stationary Maypoles, as well as the smaller still carried about, decked with ribbons and gay shreds, may be remotely connected with rag-bearing trees and bushes. $\dagger$ Once, too, when wandering about St. Blaisen in the Black Forest, where the vast Benedictine Abbey recalls so much learned labour, I happened to turn up a narrow picturesque ravine that ran inwards laterally from the fir-clad valley; after penetrating this for some distance, I observed a narrow path, seeming well-trodden, slanting upwards from the bottom. On following this for about half the ascent, it passed under a rocky wall in which a small niche had been hollowed, containing a plaster group of the Crucifixion with the Virgin and St. Mary, defended from the weather by a pane of glass let in. Immediately opposite, on the other side of the path, stood an aged thorn-bush, from which more than one stock had evidently decayed, and on the remaining

* Pope, "Dunciad."

$\uparrow$ A very primitive form of the Marpole seems to be the customs of the Garros in Eastern India, recorded by Colonel Godwin Austen ("Journal Anthrop. Inst.," vol. ii, 392,) of setting up variously carved and peeled posts, to avert sickness or ill-luck, and bamboo stakes, split at the head and opened out to carry offerings. 
stem and branches, fifteen or twenty pieces of rag and cloth, all some shade of red, were tied. I could hardly doubt that this was a primitive mark of respect transmitted from Pagan times to Christian usage.

The custom of tying rags and shreds to bushes near wells and springs reputed salubrious, once common over England and Scotland, is still frequent in France. One instance within my knowledge is at Wierre-Effroy, about fifteen miles north from Boulogne, where the water of St. Godeleine's well is held to be most efficacious for ague, rheumatism, and all ailments of the limbs ; and a quantity of crutches, bandages, pieces of rolls of rag, and the like are hung upon the neighbouring bushes as thank-offerings and testimonies of recovery; other springs in the neighbourhood are famous for curing ophthalmia, \&c. Perhaps it may be too bold to think that in Boulogne itself may be seen a signal instance of the same custom, transformed indeed in manner and manifestation, but arising from the same motives. Few continental churches are more familiar to the English than the Cathedral of our Lady of Boulogne, and many may have wondered at the countless offerings in the shape of hearts, which, sometimes homely, often costly in design and material, stud the walls of the stately church, and hang upon the sides of the splendid chancel that encloses the exquisite marble group of the Virgin in the miraculous boat. The Sacred Heart is now a favourite symbol of popular devotion; and in gratitude for inward healing and consolation, is offered and suspended in a thousand churches like shreds upon bushes by the holy wells. To such heights may even a common bush and dirty rags be lifted and transfigured by spiritual enthusiasm.

Another variation, doubtless from the same origin, may be seen in the custom prevailing all over Europe, as once in England, of offering imitation models of crippled or diseased limbs at shrines of reputed healing efficacy, either in hope of a cure, or in gratitude for health regained. Great concourses of the sick and maimed come from afar with these objects, as Heine writes in his pathetic poem of "A Pilgrimage to Kevlaar":-

"And whoso a wax hand offers,

His hand is healed of its sore;

And whoso a wax foot offers,

His foot will pain him no more."

No more remarkable instance of a blending of all these customs exists than the shrine of Notre Dâme de la Garde, venerated by seafaring men throughout the Mediterranean, where the Black Virgin looks down from her lofty chapel over the town and harbour of Marseilles. The interior presents a 
perfect forest of ex voto offerings suspended on the walls and from the roof,- - cast off crutches, models of limbs, anchors, fish, and of vessels, ostrich eggs, pieces of rope and rigging, and endless pictures commemorating deliverances from storm, battle, accidents by land, water, sickness and imprisonment,- - " memores tabellæ," as multitudinous as ever clustered round the mythic Thessalian oak in the grove of Ceres, or were hung, witis drenched garments, in the sea-god's temple.*

The origin and development of all these observances seem traceable to the rag-bushes and rag-trees, common now, and in all recorded ages, in every quarter of the Old and New Worlds. The beginnings of a custom so universal and so ancient may be due to the impulse, especially strong in rude untaught humanity, to make some offering or recognition, however trifling, to an apprehended supernatural power or presence, in token either of respect or of petition for something desired, or of acknowledgment for a benefit received. Travellers in deserts and waste countries, when passing some sacred or haunted spot, with little that could be easily spared to offer, might hold shreds torn from garments the readiest means of showing some mark of recognition, and leave them as substitutes for the complete garments and better gifts that custom would otherwise have demanded. Poor pilgrims, journeying wearily from afar, might come to regard a rag or thread, or crooked pin, a sufficient remembrance and representative of the offerings due to the spring or tomb whence they expected relief. Partly from necessity, and partly from changes of fashion and feeling, any trivial objects ready at hand-horns, bones, tufts of hair, shreds, and the like-might be used as substitutes, and continued as survivals, of more valuable gifts; so there have been ages when costly offerings were made at funerals and buried with the dead, but these have always had a tendency to change and lessen in worth, and at last to be continued in imitations or trumpery substitutes. Thus inferior pottery, evidently made for the purpose, is often found in barrows of an epoch when far better earthenware was manufactured, examples of which are also found buried; and the Chinese, who once offered gold vessels and ornaments at ancestral tombs, are now content to make them in gilt paper. Indeed, there is a custom general throughout China of offering mock food and mock garments to ghosts, especially such as have left no relations, or whose

* "Me tabula sacer

Votiva paries indicat uvida

Suspendisse potenti

Testimenta maris Deo."

"Horat." lib. i, 5. 
kindred are too poor to provide the usual offerings, but who, if neglected, are apt to be malicious, cause epidemics, and do much harm. On the 17 th of the 7 th month, a ceremony is very generally observed, called "Appeasing the burning mouths," which consists in putting out stale food and cakes and wornout clothing, with invitations above to the "Honourable Homeless Ghosts." In the same way, with regard to rag-bushes, particularly at spots where persons have died by violence, it is conceivable the shreds may be survivals of garments and offerings once left for the shivering angry ghost.

It may seem extravagant to surmise that a vestige of an analogous custom may be detected in pre-historic times, though it is natural to look there for the beginnings of immemorial observances. Explorers have often been surprised at the immense amount of broken pottery found mixed with the mould in barrows and ancient graves. Canon Greenwell, in his exhaustive work on British barrows, often refers to this, remarking on the very large quantities of potsherds met with, which certainly could not have found their way into the barrows accidentally, but seem as if they had been scattered about when the mound was being built. Such pottery is always broken, apparently made for the purpose, and, he thinks, must have symbolised some religious ideas (see pp. 11, 101, 221).

Perhaps this may be illustrated by a passage in Mr. Stanley's marvellous " March across the Dark Continent," where at a spot before unseen by Europeans he writes (vol. ii, 453): "Close to our camp was a cemetery of a village of Mbinda. The gravemounds were neat, and by their appearance I should judge them to be not only the repositories of the dead, but also the depositories of all the articles that had belonged to the dead. Each grave was dressed out with the various mugs, pitchers, wash-basins, tea-pots, glasses, gin, brandy, and beer-bottles. The various articles thus exhibited, especially the useful articles, had all been rendered useless,"-like the broken pottery of the barrows and the torn shreds of the rag-bushes. A quaint drawing of the graves accompanies the account, and is further suggestive of the analogy. It is remarkable that at a recent meeting of this Society, Mr. Seebohm described a similar custom existing in the remote regions of Central Siberia, where after a funeral feast the drinking vessels are broken and thrown upon the grave.

To conclude, such is the vitality of primitive customs, that though rag-bushes have disappeared from our springs and wells, one may venture to think they have of late years re-appeared amongst us in another guise; and that the Christmas Trees, dressed out with lights, ribbons, streamers, and all sorts of gay 
and pretty trifles, round which such joyous ceremonials are held, may be derived, like the Christmas holly and misletoe, from ages and observances long passed away, and are but changed survivals of the Pagan rag-trees.

\section{Discussion.}

Mr. KEANe was able from personal observation to confirm Mr. Walhouse's remarks touching the persistence of these practices in various parts of Ireland and elsewhere. He drew attention to several analogous customs still prevalent, especially in Munster, and acquiesced in the view that many of these superstitions had their origin in remote, possibly even pre-historic times. But he did not think it would be always safe to build any arguments for the affinity of races on the prevalence amongst them of such customs. These things may in some cases have easily been passed on from tribe to tribe, and so have ultimately made the round of the globe, without at all obliging us to assume any common relationship between peoples now found practising them. Other custorns again were doubtless the spontaneous outcome of the deeply-rooted sentiment, universal in the infancy of mankind, which has been expresser by the term Anthropomorphism; hence may well have grown up in many centres independently of any ethnical kinship. He dwelt on this point because of the disposition often shown by ethnologists to seize upon such common social traits as so many proofs of racial affinity. Of all the points usually urged in favour of such affinity-physique, language, mythology, tradition, superstitions, practices-the last was perhaps the least to be relied upon.

Mr. R. B. HoLt, M.R.S.L., referred to the presence of rags on a tree near San Antonio in Guatemala. The explanation of this form of decoration is that when a male child is born to an Indian, the father hastens to this secluded spot, and fastens up the strange offering to the woodland deity. This is supposed to ensure strength to the child, and enable him in future years to ascend the Cuesta. (Whetham's "Across Central America," page 100.)

Mr. HYDe Clarke said, in confirmation of Mr. Walhouse's paper, that in those parts of Asia and Africa where he had seen rags on tombs and bushes, they were applied indifferently by Mussulmans and Christians, and that any such object was venerated by either. It was not peculiar to any religion nor regarded as sectarian. 